\title{
The Evaluation of Has-23000 Implementation in Sate Bandeng Industry Certified of Halal
}

\author{
Mirajiani $^{1 *}$, Wahyu Susihono \\ *Correspondence:pmy_wahyu@yahoo.co.id \\ ${ }^{1}$ Agribusiness Department, Agriculture Faculty, University of Sultan Ageng Tirtayasa, Banten, Indonesia \\ ${ }^{2}$ Industrial Engineering Department, Engineering Faculty, University of Sultan Ageng Tirtayasa, Banten, Indonesia
}

\begin{abstract}
The requirement for HAS-23000 is an obligation for all companies that have obtained halal product certification by LPPOM MUI. The purpose of this application is to ensure that work procedures are maintained as part of completing the criteria and procedures for handling halal products. Milkfish satay is generally produced on a home industry scale. It was found in the field that there is no industry on a large scale that uses fish into satay milkfish, so based on the database in LPPOM MUI Banten Province there are 9 halal certified Small and Medium Industries (SMI). This study aims to determine the level of application of HAS-23000 in halal certified milkfish satay industry in Banten Province, so that in the end this data is used for basic policy making to help local governments to intervene in the program. This research method is in the form of exploration design. Observations were made directly and in-depth interviews were conducted with company management or employee representatives who worked for at least 6 months. The results showed that the implementation of HAS-23000 had been carried out by producers in the form of a) training and education, b) product names and c) the use of production facilities. While the HAS-23000 criteria that have not been carried out by the company are a) halal policies, b) the establishment of halal management teams, c) written procedures for critical activities, d) traceability, e) SOPs for critical criteria products, f) internal audits and $g$ ) management review. The company needs to increase the 11 criteria contained in the HAS-23000 so that the guarantee of halal products is maintained and the SJH manual can be prepared in accordance with the provisions.
\end{abstract}

Keywords: HAS-23000, Sate Bandeng, Halal

\section{INTRODUCTION}

The current trading system has caused changes, both in terms of global competition and in changes in behavior and paradigms in producers and consumers. Demands for high product quality standards that guarantee the safety and origins of products are of high concern to the international community at this time. Including the Muslim community who are increasingly critical and ask for high guarantees of halalness and the quality of the products that they will consume. Every company that certifies halal products has the obligation to implement a Halal Assurance System (SJH) according to HAS 23000 Standards from LPPOM MUI. This system is intended to maintain the consistency of halal products produced. SJH implementation is carried out through an internal halal management team whose daily responsibility is in accordance with their respective fields of duty. The team consists of various parts involved in critical activities and has the required competencies in carrying out their duties to maintain the halal of materials, production processes, and facilities used so that the final product is halal as the company claims to be known by consumers. Halal certification plays an important role in conveying product information to consumers, that the product has a halal guarantee (Raymond, 2000). Halal certification aims to ensure that the product is marketed in a good way so that it is well received by the consumer or another issue is not misleading the consumer (David and John, 1997).

Consumers from various halal-labeled products have been very widespread found on the market, not only Indonesian Muslims, but residents in several other countries also take part in halal attention, as evidenced in several restaurants in Malaysia that are halal certified, because in addition to being safe for Muslim consumption also participating in improving business competition, because food is a basic need for humans and is always needed every time Rezai et al (2012) and Rahim et al (2013). In each company or IKM that has obtained halal certification, it should have implemented a Halal Assurance System (Sistem Jaminan Halal-SJH), however, many are found in the field when making SJH is not yet standard in accordance with HAS 23000. This condition provides an opportunity for non-certified products to be maintained so that various performance evaluations of the implementation of the Halal Assurance System (SJH) to IKM Sate Bandeng.

In general, the SJH manual is created and reported by Halal auditors during a visit in the field, so that the role of the auditor in addition to seeing products (product matrix) in halal conditions or status, also contributes to making a halal manual form in the form of $\mathrm{SJH}$. This condition shows that 
the halal knowledge transfer from $\mathrm{SH}$ auditors with IKM is very important. At the time of the initial submission to obtain SH from IKM, it was felt easy, but at the time of submission of the $\mathrm{SH}$ extension from the IKM, it became a separate problem, because the obligation of IKM was to make the SJH manual. The SJH manual is a must in submitting new and extended halal product certification. Without a performance evaluation related to the technical implementation of the $\mathrm{SJH}$ manual, the IKM is possible to experience difficulties in maintaining consistency in maintaining the matrix of material and matrix products by the company. When the Law No. 33 of 2014 has been enacted, the SJH audit will become mandatory before the company is scheduled to audit the product.

The complexity of products and materials is an inseparable part of the SJH manual. There are 11 criteria in the halal guarantee system that must be prepared in addition to other supporting data which is an integral part.

Food is the main thing that has high value for human life especially Sate Bandeng which is processed by Banten Province Products. Humans as consumers have an instant attitude, especially in their consumption of food especially in the development of the Bandneg Satay. A well-known brand makes various producers need to apply sustainable competition, along with the addition of raw materials and other materials must be known for the consistency and absence of non-halal or subhat ingredients. Syubhat is an unclear halal status or still in the dubious category (Apriyantono et al, 2001).

This research has high relevance and importance, due to the issuance of the Halal Product Guarantee Act (Undang-Undang Jaminan Produk Halal-UUJPH). The JPH Act was issued on October 17, 2014, meaning that in this law in 2019 the UUJPH will be effective after the Government Regulation (PP) is issued, at this time it is the right time to conduct an evaluation related to the implementation of the company's halal internal auditor performance so that there is a wider difference between the implementation in the industry with the HAS-23000 standard issued by LPPOM MUI.

\section{METHODOLOGY OF RESEARCH}

This research method is in the form of exploratory design. Observations are carried out directly and deep interviews are conducted with company management or employee representatives who work for at least 6 months in a row. The research location was 9 valid halal certified Sate Bandeng industry from Banten Province LPPOM MUI. The Research aims to make a description of a social or natural phenomenon systematically, factually, and accurately (Wardiyanta, 2006), research by obtaining data in the form of numbers or qualitative data (Sugiyono, 2003).

\section{RESULTS AND DISCUSSION}

LPPOM MUI is an institution established by the Indonesian Ulema Council (MUI) on January 6, 1989 in Jakarta which has a role to carry out the function of protecting Muslim consumers in Indonesia in consuming halal food, beverages, medicines and cosmetics which aims to provide inner peace for Muslims, especially in the effort to consume food, medicines and the use of cosmetics (Bungin and Burhan, 2007). The formation of LPPOM MUI was initially triggered by the spread of the issue of lard which was very troubling to some Indonesian people, causing sentimental markets, especially some types of food production. product (LPPOM MUI. 2009; 2011)

The rapid development of information technology has an impact on increasing consumer awareness of the use of halal products (Lada, 2009). The SJH Manual is structured to guide the implementation of $\mathrm{SJH}$ in companies, in order to maintain the continuity of halal production processes in accordance with the requirements of LPPOM MUI. The SJH Manual is an SJH implementation document in the Company that is based on HAS 23000 Halal Certification Requirements and HAS 23301 SJH Manual Preparation Guidelines in the Processing Industry. The SJH manual applies to all Company units related to halal production processes, including maklon and rental warehouses. The application of SJH applies to all of the Company's products circulating in Indonesia, both products manufactured by the factories themselves and those produced by the maklon factory. 
Table 1. Product names and halal certificate numbers

\begin{tabular}{lc}
\multicolumn{1}{c}{ Product Names } & \multicolumn{1}{c}{$\begin{array}{c}\text { Halal Certificate } \\
\text { Numbers }\end{array}$} \\
\hline Sate Bandeng - Rumah Ratu Sabanban & 17030030940417 \\
Sate Bandeng - Saba Kota & 17030031310517 \\
Sate Bandeng - Priyai & 17030027591116 \\
Sate Bandeng - Hasnah Produk- & 17030028831116 \\
Sate Bandeng - Priyai & 17030027591116 \\
Sate bandeng - Asep Kamal & 17030026580916 \\
Sate Bandeng - CV. Anugrah Sabajo Indonesia & 17030038580518 \\
Sate Bandeng - Andi & 17030020191015 \\
Sate Bandeng - Mak Endek & 17030040770718 \\
\hline
\end{tabular}

Implementation of the Halal Assurance System (SJH) in general is still found to be a variety of obstacles, one of which is the absence of a truly effective method for analyzing the substance of food products that truly guarantee the halalness of a food product (Apriyantono, 2001). The survey results show that out of 9 companies engaged in processing Sate Bandeng, in the implementation process of HAS-23000 there are several criteria that have not been tested, including the following can be seen in table 2:

Table 2. Implementation of Has- 23000 in the processing industry of 9

IKM Sate Bandeng which is in Banten Province

\begin{tabular}{|c|c|c|c|c|c|c|c|c|c|}
\hline $\begin{array}{c}\text { Criteria of HAS- } \\
23000 \\
\end{array}$ & $\begin{array}{c}\text { IKM- } \\
1\end{array}$ & $\begin{array}{c}\text { IKM- } \\
2\end{array}$ & $\begin{array}{c}\text { IKM- } \\
\mathbf{3}\end{array}$ & $\begin{array}{c}\text { IKM- } \\
4\end{array}$ & $\begin{array}{c}\text { IKM- } \\
5\end{array}$ & $\begin{array}{c}\text { IKM- } \\
6\end{array}$ & $\begin{array}{c}\text { IKM- } \\
7\end{array}$ & $\begin{array}{c}\text { IKM- } \\
8\end{array}$ & $\begin{array}{c}\text { IKM- } \\
9\end{array}$ \\
\hline \multicolumn{10}{|l|}{ Halal Police } \\
\hline $\begin{array}{l}\text { Halal Management } \\
\text { Team }\end{array}$ & & $\sqrt{ }$ & & & $\sqrt{ }$ & & & $\sqrt{ }$ & \\
\hline $\begin{array}{l}\text { Training and } \\
\text { Education }\end{array}$ & $\sqrt{ }$ & $\sqrt{ }$ & $\sqrt{ }$ & $\sqrt{ }$ & $\sqrt{ }$ & $\sqrt{ }$ & $\sqrt{ }$ & $\sqrt{ }$ & $\sqrt{ }$ \\
\hline Material & $\sqrt{ }$ & $\sqrt{ }$ & $\sqrt{ }$ & $\sqrt{ }$ & $\sqrt{ }$ & $\sqrt{ }$ & $\sqrt{ }$ & $\sqrt{ }$ & $\sqrt{ }$ \\
\hline Product & $\sqrt{ }$ & $\sqrt{ }$ & $\sqrt{ }$ & $\sqrt{ }$ & $\sqrt{ }$ & $\sqrt{ }$ & $\sqrt{ }$ & $\sqrt{ }$ & $\sqrt{ }$ \\
\hline Production Facilities & $\sqrt{ }$ & $\sqrt{ }$ & $\sqrt{ }$ & $\sqrt{ }$ & $\sqrt{ }$ & $\sqrt{ }$ & $\sqrt{ }$ & $\sqrt{ }$ & $\sqrt{ }$ \\
\hline \multicolumn{10}{|l|}{$\begin{array}{l}\text { Written Procedure for } \\
\text { Critical Activity }\end{array}$} \\
\hline Research Capability & & $\sqrt{ }$ & & & $\sqrt{ }$ & & & $\sqrt{ }$ & $\sqrt{ }$ \\
\hline $\begin{array}{l}\text { Handling of products } \\
\text { that do not meet the } \\
\text { criteria }\end{array}$ & & $\sqrt{ }$ & & $\sqrt{ }$ & $\sqrt{ }$ & & $\sqrt{ }$ & $\sqrt{ }$ & $\sqrt{ }$ \\
\hline \multicolumn{10}{|l|}{ Internal Audit } \\
\hline Management Review & & & & & & & & & \\
\hline
\end{tabular}


Some companies have not implemented all the possible HAS-23000 criteria, including the IKM pursuing product audits, where the form only provides material and product matrix, while the SJH manual has not been made by the company management, or it is possible that the system is not ready, labor or HR has no one understood and understood the SJH manual. It is recommended that the company owner take part in the Halal Assurance System (SJH) training held by LPPOM MUI in each period so that in addition to functioning as a fulfillment of the HAS-2300 criteria in the third step, it is also an educational process for upgrading SJH preparation.

\section{Halal Policy, Halal Management Team, Training and Education}

The halal policy has not been compiled and has not become part of the company's commitment, in this case by the head of the company, because almost all of the IKM Sate Bandeng does not have a halal policy. In general, the contents of this halal policy are statements that the company is determined to only produce and market halal products consistently in order to meet consumer needs and prioritize customer satisfaction through innovation.

Measures or efforts to realize this halal policy commitment can be carried out through the program (a) guaranteeing that the production system is clean and free from non-halal and unclean material, (b) training, developing and involving all stakeholders of the company to understand the Halal Guarantee System, (C) providing the resources needed for the preparation, implementation and continuous improvement of the Halal Guarantee System, (d) conducting socialization of halal policies to all company stakeholders through socialization media such as training, briefings, internal memos, banners, posters, or other forms of socialization that are appropriate to the needs of the company.

The halal management team was formed as part of the wheel of halal policy that has been established in the company. Training and education are carried out as targets and initial annual plans and at least within 2 years have participated in the training held by LPPOM MUI. The nine IKMs that are the subject of research have not applied or had a halal policy, but there are several IKMs that already have a halal management team consisting of company owners and several employees, but the implementation is not optimal. Training and education are generally carried out by company owners in the form of participants in the socialization organized by assistance from related agencies in Banten province, as well as independently participating in the Halal Assurance System training organized by the MUI LPOM on the last Tuesday of the month.

\section{Material, Product and Production Facilities}

The law regarding halal products refers to the Al-Qur'an and Hadith, as in Al Qur'an Surat Al-Baqarah verse 168. Stating that "All men, eat the lawful again from what is on earth, and do not follow devil steps; for verily the devil is a real enemy to you "(Qur'an 2: 168). Whereas in the Quranic verses. Surat Al Baqarah: 173, stated that "Verily Allah forbids you carcasses, blood, pork and slaughtered by names other than Allah. In general, to obtain halal product certificates, IKM must have an SJH station at least B. SJH Status Fulfillment Division, at least from the raw materials used, production facilities used and the name of the product which is from halal material and there is no non-halal contaminant and is not unclean or the like. Do not violate existing provisions, including IKM only using materials in accordance with what has been registered at the time of the initial audit through matrix material forms. List of materials (raw materials, auxiliary materials and auxiliary materials) that are used to produce certified products, if it will make repairs both addition and replacement of materials with other brands, then the repair of the materials list is sent to LPPOM MUI to be known, checked and signed by LPPOM MUI every six months.

The provision of product naming refers to things that are indeed allowed by LPPOM MUI, including companies committed to producing halal products with product names that do not use names that lead to something that is forbidden or worship that is not in accordance with Islamic sharia, and sensory profiles or characteristics, and does not have a tendency to smell or taste that leads to illicit products or those that have been declared haram based on the MUI fatwa. Whereas, for non-retail (non-retail) food products that have brands/brands and are only partially registered, the IKM needs to include the MUI halal logo for certified products. The label is a loose binding affixed to a particular product (Angipora, 2007). Halal labeling is an obligation if the producer is devoted to the consumption of Muslims and is a process in guaranteeing that the product has been certified by LPPOM MUI (Ahmad and Sutarno, 2014). A food product that is not labeled, it is possible that it will have a negative impact on human health because of the absence of a process or procedure for good substance management (Ministry of Religion, 2003)

The product facilities used by IKM generally refer to the conditions required, including production facilities to produce halal products not used interchangeably for products containing pigs or their derivatives. However, production facilities that have been used to produce products that contain pigs or their 
derivatives, are washed seven times with water and one of them with soil or other material that has the ability to eliminate taste, odor, and color. When the production process is complete, the storage process for materials and products in a warehouse or in a temporary warehouse will guarantee the absence of cross-contamination with materials or unclean or unclean products.

\section{Written Procedure for Critical Activity}

The implementation of the written procedure criteria for critical activities in 9 IKMs has not been carried out because of the absence of reporting and written procedures that have been carried out. Some of the provisions carried out include management or an internal halal management team that needs to record all purchase transactions and keeps proof of purchase complete with the brand and code. Every ingredient coming before production use is checked the suitability of the information on the material packaging label with the information contained in the supporting material document. The information examined includes the name of the material, the name of the producer, the producer country and the presence of a halal logo if required. Ensure that halal products of the company are well distributed, ie not crosscontaminated with other halal products. The company is committed to registering new products with the same brand to be certified halal before being sold on the market.

\section{Research Capability}

Not all IKMs have recorded and carried out bookkeeping properly. IKM needs to make a neat administration and documentation system so that it will be easier to trace again if problems occur in the implementation of halal production.

\section{Handling of products that do not meet the criteria}

The handling of products that do not meet the criteria includes the existence of written procedures on how to deal with products that do not meet the criteria. In general, IKMs in the new Sate Bandeng processing industry do a separation of products that are not suitable for consumption or sale. Handling of products is carried out physically and will not mix products that are not suitable for consumption with new processed ahsil products.

Products derived from materials and production facilities that do not meet criteria are separated to avoid contamination during the production process. The handling of products derived from materials and production facilities that do not meet the criteria are removed from the process area to avoid contamination and products sent to consumers. If a product that does not meet the criteria has already been sold, then the product must be withdrawn from the market.

\section{Internal Audit, Management Review}

Because the company's internal team has not yet been formed, the implementation of internal audits including the management review process has not been implemented in almost all the IKM Sate Bandeng. In general, the limitations of management that make the reasons for these two criteria have not been run optimally. Even though the team created can come from the owner of the company, even from employees or workers in the IKM, the system can be formed properly.

The Halal Internal Audit aims to independently evaluate the implementation of the Halal Assurance System in the SMIs so that it is expected to know the shortcomings of $\mathrm{SJH}$ implementation. Internal audits carried out on a scheduled basis at least once every six months or more often if required with the scope of the internal audit are the implementation of all aspects of the Halal Assurance System (11 criteria) and proof of implementation. If the internal audit finds weaknesses or non-conformities of $\mathrm{SJH}$ implementation in a company with halal certification requirements including policies, procedures, and criteria in the company or IKM, corrective action will be taken immediately.

Some of these constraints made possible the need for education and training for LPPOM MUI because it was believed that this did not mean that IKM was not able to, but because of their ignorance or lack of clarity in managing the system which was part of the process improvement. Some IKMs still need an in-depth evaluation of the implementation of SJH. As reported in other studies states that it is possible because of constraints on the adoption of halal science and products that are still limited (Syed and Nazura, 2011) in Husain, et al (2012). LPPOM MUI and the local government need to jointly evaluate and mentor SMIs who have obtained halal certificates. The government needs to take a role and be part of the seriousness of halal management (Soesilowati (2010).

\section{CONCLUSION}

a. Compliance with the implementation of HAS23000 that has been carried out by producers in the form of training and education, product names and use of production facilities.

b. The HAS-23000 criteria that have not been carried out by the company are halal policies, the establishment of halal management teams, written procedures for critical activities, traceability, SOP handling 
products that do not meet critical criteria, internal audits and management reviews.

c. The company needs to improve 11 criteria contained in HAS-23000 so that the guarantee of halal products is maintained and the SJH manual can be prepared according to the provisions.

\section{REFERENCES}

1. Ahmad, M. Sutarno, Y., (2004). Hukum Perlindungan Konsumen. PT. Raja Grafindo Persada. Jakarta

2. Angipora., (2007). Dasar-Dasar Pemasaran. Edisi Kedua. Cetakan Kedua. PT. Raja Grafindo Persada. Jakarta.

3. Apriyanto., A. (2013). LPPOM MUI Harus diperkuat. Jurnal Halal. No 99 th XVI. Jakarta; LPPOM MUI

4. Apriyantono, A. Hermanianto, J. Nurwahid., 2003. Pedoman Produksi Halal. Departemen Agama Republik Indonesia.

5. Bungin, Burhan. 2007. Penelitian Kualitatif Edisi Kedua. Kencana Prenada Media Group. Jakarta

6. David, O dan John. L., (1997). Text Book on Consumer Law. London: Blackstone Press Limited

7. Departemen Agama., (2003). Petunjuk Teknis Pedoman Sistem Produksi Halal; Dirjen Bimas Islam dan Penyelenggaraan Haji

8. Ghazali, (2002)., Benang Tipis Antara Halal Dan Haram. Putra Pelajar. Surabaya

9. Lada, S. Harvey. G. Amin., (2009). Predicting Intention to Choose Halal Products Using Theory of Reasoned Action. International Journal of Islamic and Middle Eastern Finance and Management. 2 (1): p66 - 67

10. LP POM MUI. (2009). Jurnal Halal: Menentramkan Ummat. No. 78 Th. XII

11. LP POM MUI. (2011). Jurnal Halal: Menentramkan Umat. No. 88 Th. XIV

12. Rahim, N.F. Shafii, Z, Syahidawati., 2013. Awareness and Perception of Muslim Consumers on NonFood Halal Product. Journal of Social and Development Sciences. 4(10): 478-487.

13. Raymond, O’Rourke., (2000). Food labeling is one of the main areas of food law and the food label plays an important role in communicating vital information to the consumer about different food product; Food Safety and Product Liability. Bembridge: Palladian Law Publishing,

14. Rezai, G. Zainalabidin, M. Mad, N.S., (2012). Non-Muslim Consumers' Understanding of Halal Principles in Malaysia. Journal of Islamic Marketing. 3(1): p35-46.
15. Soesilowati, E. S., (2010). Business Opportunity for Halal Products in Global Market: Moslem Consumer Behavior and Halal Food Consumption. Journal of Indonesian Social Science and Humanities. 3: 151-160 